\title{
Pepetela: romance e utopia na história de Angola
}

Rita Chaves*

\author{
* Universidade de São Paulo.
}


Em entrevista concedida a Michel Laban, em 1988, e publicada no livro Angola - encontro com escritores, ao falar sobre Muana Puó e as diferentes fases de sua obra, Pepetela observa:

“Parece-me que as preocupações de fundo, em Muana Puó são as mesmas de todo o resto que foi escrito depois. Há um tema que é comum, que é o tema da formação da nação angolana. Isso faz o denominador comum." ${ }^{\prime 1}$

Antes de buscarmos a pista dada pelo autor, é interessante, para nos aproximarmos de "todo o resto que foi escrito depois", examinar a sua bibliografia, tarefa que permite também situar a sua dimensão no sistema que integra. R eunindo já treze títulos , dos quais apenas três publicados no B rasil, Pepetela divide com J osé L uandino Vieira o estatuto de escritor mais conhecido e premiado de Angola. Para citar apenas dois, apontamos o "Prêmio da Associação Paulista de Críticos de Arte" (em 1993) e o Prêmio Camões (em 1997). O levantamento de sua produção demonstra ainda que a repercussão de seu trabalho já vai além das fronteiras da língua portuguesa. Para muito além, eu diria mesmo, uma vez que Mayombe , foi publicado inclusive no J apão, numa edição "linda, onde só se pode reconhecer os números das páginas e um mapinha de Angola na contracapa", segundo bem humorada declaração do próprio romancista. 
A leitura do conjunto da obra, incluindo-se os títulos publicados após a entrevista, vem, com efeito, confirmar a construção da nacionalidade como um tema constante que, sob vários ângulos e perspectivas, constitui um elemento matriz em seu repertório. Se saímos do particular e alcançamos o geral, ou seja, o conjunto da literatura de Angola, reconhecemos que a formação da identidade nacional é na realidade uma das linhas de força da consecução desse sistema literário. Com décadas de diferença, os escritores angolanos passam pela experiência que viveram os nossos românticos e reviveram, de maneira diferenciada, os nossos modernistas: fazer uma literatura que interviesse no processo de definição do país. Se a questão parece-nos antiga, há que recordar que o país é novo: passaram-se apenas 22 anos desde a sua independência e o problema da função da obra literária e do papel social do escritor se recoloca, senão com outras cores, pelo menos, com novos matizes. É preciso examiná-los, ainda que não se disponha da perspectiva histórica que o tempo há de abrir e que o instrumental analítico tenha sido forjado para o estudo de outro universo cultural.

Se o tema central não singulariza Pepetela no interior do sistema literário angolano, há outro elemento capaz de marcar a sua diferença : ele é hoje o único nome quase que exclusivamente identificado com o romance como forma de expressão. Associad o ao mundo da escrita, esse gênero literário exerceu desde sempre uma impressionante atração sobre os escritores angolanos em que pese à sua inserção num universo cultural marcado pela tradição oral. A despeito desse fascínio, a obra de seus companheiros, como J osé Luandino Vieira, Arnaldo Santos, Costa Andrade, Manuel Rui, Henrique Abranches, entre outros, divide-se entre contos e romances, romances e poemas, poemas e contos. E mbora tenha publicado alguns contos nas antologias da famosa Casa dos Estudantes do Império, ainda no tempo de estudante em Lisboa, e, por duas vezes, se tenha enveredado pelo teatro, é como autor de narrativas longas que ele se inscreve no projeto literário angolano. A té o momento são dez as já editadas, se aí incluímos As aventuras de Ngunga ( obra escrita em circunstâncias especiais com destinação especial ). De Muana Puó a A gloriosa família, passando por Mayombe, Yaka., O cão e os caluandas, Lueji , A geração da utopia, O desejo de kianda , e a Parábola do cágado velho, o autor tem se mantido fiel ao gênero que cedo escolheu para dar curso ao seu projeto literário.

Aproveitando do gênero, o senso de historicidade, a lógica da causalidade histórica, Pepetela organiza a sua visão do que tem sido aquela sociedade. E , combinando elementos internos ao quadro literário angolano com as marcas provenientes de outros processos, ele vai escolhendo as referências que melhor podem servir a sua proposta. Assim, do lado de dentro, é possíver ver a sua obra como tributária da produção de Castro Soromenho, escritor que constitui um curioso 
caso no terreno da nacionalidade. Filho de pais caboverdianos, Soromenho nasceu em Moçambique, foi funcionário do governo colonial português em Angola, esteve por um bom período em Portugal, exilou-se em Paris, e veio a morrer no Brasil, onde participou da organização do Centro de Estudos Africanos da Universidade de São Paulo. Em meio a essa pluralidade de países, Castro Soromenho optou por Angola como marca de identidade e é sobre a região da L unda, situada no nordeste do país, que ele vai concentrar o seu olhar de escritor. Num paralelo com Pepetela, a convergência aponta a natureza ensaística dos textos (através da familiaridade com as lições da Antropologia, da E tnologia, da Sociologia e da História) . No campo dos elementos estruturais do romance, destaca-se a relevância dada ao espaço na organização textual. Sobretudo em Terra morta , A chaga e Viragem , os sinais da terrível crise do sistema colonial projetam-se na terra. Toda a aridez do tempo faz-se refletir no chão poeirento que asfixia as personagens e anuncia a falência da ordem instalada. Essa concepção do espaço que se eleva e atua como elemento de forte significado na ordem narrativa será também um traço decisivo em obras como Yaka, O cão e os calus e O desejo de Kianda, para citar apenas três do Pepetela.

$\mathrm{N}$ a relação com os elementos externos, podemos assinalar a marca das propostas do Neo-realismo português, da literatura norte-americana (Hemingway, Steinbeck e S. Fittzgerald ) e do romance brasileiro voltado de modo direto para as questões sociais. Nesse campo, tal como ocorreu com a maior parte dos escritores africanos de língua portuguesa a partir dos anos 40, a fonte será sobretudo o nosso regionalismo da década de 30. A J orge A mado, J osé L ins do R ego e G raciliano R amos associa-se na preferência por uma linguagem mais direta, um estilo seco, calcado no desejo de revelar as agruras de uma situação injusta e, por isso, passível de mudança. Nessa grande família, aproximada pela dimensão popular presente em seus projetos, procurou se situar Pepetela, sempre ligado a um projeto apto a catalisar questões que pudessem definir o ser ( e o estar ) angolano.

Fortalecido com os ensinamentos que, sem preconceito, retira da experiência de escritores de outras terras, mas apoiado na sua própria experiência, P epetela firma o seu itinerário e organiza as linhas de uma obra onde se pode recolher fios expressivos da própria história de Angola. Talvez mais do que em qualquer outra produção estejam visivelmente assinalados na sua as representações, os impasses e as contradições da história recente do país. A indisfarçada preocupação com os problemas em torno da formação da nacionalidade pode explicar a continuidade de um projeto em cujo interior se manifestam as diversas rupturas que o próprio desenvolvimento da História impõe. Se tomamos o tema da utopia como uma chave central, é possível, sem esquecer as particularidades do texto literário, ver de que modo os avanços, os recuos e os desvios no projeto elaborado nos anos 50. 


\section{Faz-se uma utopia e nasce uma nação}

Para fazer essa travessia, um bom ponto de de partida é o romance Mayombe, cujo enredo desvela as dimensões várias daquelas horas em que se está gestando a utopia da libertação nacional. Na floresta situada em Cabinda, os guerrilheiros fazem a luta e discutem sobre sua realização e seus desdobramentos. Ali, ameaçados por tantos perigos, perdem-se em longas conversas a respeito do que deverá ser o país após a independência. I mpressiona na montagem textual a atmosfera de diálogo marcando diversos níveis da narrativa. Sob o céu verde, conversam os guerriIheiros entre si, conversam os homens com a natureza, dialogam consigo mesmo ( $\mathrm{e}$ com o leitor a quem sutil ou diretamente se dirigem ) os muitos narradores a quem o narrador titular abre espaço para que exprimam a sua leitura das coisas. As infindáveis discussões, ao revelarem as dificuldades e a prenunciarem impasses, exprimem também a necessidade e a vontade de maior compreensão entre os vários mundos que precisam se fundir para enfrentar o inimigo maior, que ameaça suas vidas e a terra por onde se movem e onde estão instaladas muitas outras vidas.

Confirmando a importância do espaço como elemento essencial em seu texto, o autor faz da floresta muito mais do que um palco para as ações que serão narradas. Atribuindo-Ihe um papel dinamizador naquele momento da história de Angola, ele investe na sua personificação. Invadida, destruída, maltratada pelo colonizador, a natureza não chegou a ser por ele compreendida, e agora se converte ela própria em ameaça. Sua exuberância, tão cantada nas páginas da chamada literatura colonial, como evidência da grandiosidade do império português, parece revelar agora a face infernal de um mundo nunca dominado. A fragilidade de quem se julgou invencível espelha-se então na incapacidade de decifrar os mistérios abrigados em seus caminhos não traçados. I nversamente porém, os oprimidos, transformados nessa etapa em guerrilheiros, têm da floresta uma outra visão. Sua identidade com o espaço permite-lhes estabelecer com ele uma relação dinâmica, onde o imprevisto nem sempre é fonte de angústia. A imagem do labirinto pode aqui ser evocada : desconhecido, o espaço precisa ser conquistado, operação que exige argúcia e empenho de quem a ela se arrisca, daí decorrendo um roteiro de aprendizagem, no qual os atos se desenrolam como uma espécie de rito mediado também pela paixão. Não há, portanto, sinais de submissão entre os atores e o espaço; são ambos forças complementares de um especial movimento, processado sob o signo da sedução. Sob o signo da sedução, o quadro não se arma com as formas da monotonia e a relação entre a floresta e os homens é atravessada pela imprevisibilidade, numa composição em que o temor se mistura a uma dose 
de cumplicidade. A mata é o deus que inspira medo mas também oferece proteção, sentimento dúbio a distinguir os colonizados dos colonizadores :

“O passeio ao Sol ardente ainda o enfureceu mais. Não estava habituado ao Sol , sempre escondido na sombra protetora do Mayombe."2

“(...) pois deviam ir de rastos sobre as pedras. Por vezes tinham de entrar na água pouco profunda. A água estava fria e a roupa molhada colava-se em arrepios ao corpo. 0 Mayombe já recuperara o arco-iris verde. Sem Medo recebeu-o como um primeiro sinal de boas-vindas."3

A singularidade da situação exprime-se também na força dos diálogos com que se compõe o romance. Descrito pelo narrador titular como o espaço do silêncio, o Mayombe transfigura-se na verdade no reino da palavra. O diálogo se faz sempre : pelo dito, pelo não dito, realizam-se as conversas. Conversam os personagens e a mata, conversam os personagens entre si, conversam personagens e narrador. Através de expressões interrogativas que parecem convocar o leitor à discussão, introduz-se um possível destinatário que inicialmente não estaria integrado à trama. Em meio à densidade da mata, os guerrilheiros abrem caminhos e de algum modo se abrem para uma produtiva troca de experiências. A tensão é patente, mantida pelo perigo externo e pela inevitabilidade de conflitos internos, no entanto pode-se perceber também a importância da palavra como processo de organização das consciências e meio usado de forma exaustiva para assegurar a comunicabilidade entre homens, histórias e projetos. A ssim, fazendo da narrativa , alegorizada pela floresta, o espaço do diálogo, narrador e personagens em Mayombe, constroem-se a partir de um processo vivo que reúne identidades e diferenças, coincidências e dissidências, homologias e rupturas. Se consideramos que uma das estratégias do colonialismo era impedir a circulação das idéias, bloqueando as trocas culturais entre os vários grupos, percebemos a importância desse clima de exteriorização de valores e diferenças como já um ato subversivo.

A contracenar vivamente com o espaço está o foco narrativo. Assumido por vários narradores, cujas falas são organizadas por uma espécie de narrador titular, o fio narrativo é dividido e comungado pelos elementos que vivem as ações do enredo. A divisão, todavia, naquele contexto onde tudo convida à comunhão não deve ser entendida como fragmentação propriamente, mas como um sinal de que a autoridade, de que a palavra é manifestação, é, em certa medida, partilhada. Articula-se a essas marcas da democratização da voz o mencionado peso dos diálogos nesse texto, concebido inicialmente, segundo afirmou o autor numa entre-

Cf. Mayombe. Lisboa: Edições 70, 1982, p.93

Idem, p. 245 
vista que lhe fizemos em 87, para ser um roteiro cinematográfico. E nesse clima de diálogo, se percebe a formação da utopia como um princípio esperança, para citar a expressão com que E rnst B loch intitula o seu livro.

Organizados contra um inimigo comum e mais poderoso, os guerrilheiros devem vencer também os fantasmas deixados como herança pelo sistema colonial : o racismo, o tribalismo, o regionalismo como conflito. O "tuga", como eram chamados os portugueses, já não tem sequer estatuto de personagem essencial. Como uma espécie de figuração é só uma sombra que corta o caminho dos guerriIheiros. Embora a situação da guerra colonial seja evidente no texto, o romance, escrito mesmo nos intervalos do combate por um escritor fisicamente empenhado na luta, avança no tempo e refere-se a problemas que virão depois. Prevista, a vitória é assumida como um dado de realidade e essa certeza converte-a numa forma de inexorabilidade que ergue impasses e registra a necessidade de soluções. A situação aguda da crise não esbate a consciência de que a vitória significará harmonia; a relativização do alcance dos resultados é indício da profundidade de visão de quem não hesita em investir na ação. As várias falas dos narradores, compondo um vivo mosaico de propostas e sensibilidades, sinalizam para a precariedade da integração que ali se vive. Contra os riscos da desagregação como norma, se abre uma rede utópica permeada também pelas nuances de um discurso edificante. Tomemos como exemplo alguns parágrafos da fala de M uantiânvua, o ex-marinheiro que como guerrilheiro assume o nome de imperador na tradição cultural de Angola:

“M eu pai era um trabalhador bailundo da Diamang, minha mãe era um kimbundo do Songo.

O meu pai morreu tuberculoso com o trabalho das minas, um ano depois de eu nascer. Nasci na Lunda no centro do diamante. O meu pai cavou com a picareta a terra virgem, carregou vagões de terra, que ia ser separada para dela se libertarem os diamantes. M orreu num hospital da companhia, tuberculoso. O meu pai pegou com as mãos rudes milhares de escudos de diamantes. A nós não deixou um só, sequer o salário de um mes. O diamante entrou-Ihe no peito, chupou-Ihe a força, chupou, até que ele morreu

O brilho do diamante são as lágrimas dos trabalhadores da Companhia. A dureza do diamante é ilusão : não é mais que gotas de suor esmagadas pelas toneladas de terra que o cobrem.

Nasci no meio de diamantes sem os ver. Talvez porque nasci no meio de diamantes, ainda jovem senti atrações pelas gotas do mar imenso, aquelas gotas-diamante que chocam contra o casco dos navios e saltam para o ar, aos milhares, com o brilho leitoso das lágrimas escondidas. 
O mar foi por mim percorrido durante anos, de norte para sul, até a Namíbia, onde o deserto vem misturar-se com a areia da praia, até ao G abão e ao G hana, e ao Senegal, onde o verde das praias vai amarelecendo, até de novo se confundir com elas na M auritânia, juntando a África do Norte à Á frica Austral, no amarelo das suas praias. Marinheiro do Atlântico, e mesmo do Índico eu fui. Cheguei até a Arábia, e de novo, encontrei as praias amarelas de $M$ oçâmedes e B enguela, onde cresci. Praias de B enguela, praias da M auritânia, praias da A rábia, não são as amarelas praias de todo o Mundo?

Onde eu nasci, havia homens de todas as línguas vivendo nas casas comuns e miseráveis da Companhia. Onde eu cresci, no B airro B enfica, em B enguela, havia homens de todas as línguas, sofrendo as mesmas amarguras. $O$ primeiro bando a que pertenci tinha mesmo meninos brancos, e tinha miúdos nascidos de pai umbundo, tchokue, kimbundo, fiote, kuanhama.

Querem hoje que eu seja tribalista?

De que tribo ? pergunto eu. de que tribo, se eu sou de todas as tribos, não só de Angola, como de África ? Não falo eu o swahili, não aprendi eu o haussa com um nigeriano ? Qual é a minha língua, eu, que não dizia uma frase sem empregar palavras de línguas diferentes? E agora, que utilizo para falar com os camaradas, para deles ser compreendido ? O português. A que tribo pertence a língua portuguesa?

Eu sou o que é posto de lado porque não seguiu o sangue da mãe kimbundo ou o sangue do pai umbundo. Também Sem Medo, também Teoria, também o Comissário, e tantos outros mais.

A imensidão do mar que nada pode modificar ensinou-me a paciência. O mar une, estreita, o mar liga. Nós também temos o nosso mar interior, que não é nem o Kuanza, nem o Loje, nem o K unene. O nosso mar, feito de gotas-diamante, suores e lágrimas esmagados, o nosso mar é o brilho da arma bem oleada que faísca no meio da verdura do Mayombe, lançando fulgurões de diamante ao sol da Lunda.

Eu, M uatiânvua, de nome de rei, eu que escolhi a minha rota no meio dos caminhos do Mundo, eu, ladrão, marinheiro, contrabandista, guerrilheiro, sempre à margem de tudo ( mas não é a praia uma margem ? ) , eu não preciso de me apoiar numa tribo para sentir a minha força. a minha força vem da terra que chupou a força de outros homens, a minha força vem do esforço de puxar o cabo e dar à manivela e de dar murros na mesa duma taberna situada algures no M undo, à margem da rota dos transatlânticos que passam, indiferentes, sem nada compreenderem do que é o brilho-diamante da areia duma praia."4 
No discurso do personagem, temporariamente alçado à condição de narrador, projetam-se as verdades que se identificariam com a emergência desse momento novo na história de Angola de que a guerrilha constitui uma espécie de rito de passagem. Ali, onde a grande tarefa política consiste em formular uma prática que, unificando as vozes, venha conferir unidade a esse punhado de povos, raças, tradições, circula um homem que já compreendeu o que o projeto de independência não conseguira ainda ensinar a todos. A voz, associada à sabedoria, anunciadora do mundo que se deve abrir, é, não por acaso da voz do marinheiro, acumulador das experiências que as viagens trouxeram. A referência logo conduz às observações de Walter Benjamin a respeito das matrizes do narrador tradicional. Recordamos, então, da ruptura entre a tradição oral e o romance como um gênero do mundo burguês, relação tão bem discutida pelo pensador alemão. Incorporado por um projeto literário que se faz no ritmo impulsionado das transformações de base, quando estão abalados os pilares que sustentam a ordem ainda em vigor mas já em decomposição, o romance no contexto angolano tem ele próprio relativizado um de seus pontos estruturais.

Se não há possibilidade de recuperar a inteireza do narrador da tradição oral, a narrativa de Pepetela não abre mão de referir-se ao desejo de intercambiar experiências. Irrompendo contra a ordem burguesa, ali diretamente colada à empresa colonial, ambicionada, a narrativa, mesmo se consciente dos limites da mudança a ser efetivada, sinaliza a vontade de superar a incomunicabilidade. Ainda que extemporânea, a aposta na utopia se vai reiterando ao longo das muitas páginas do Mayombe. No desdobramento do projeto utópico de que a fala do Muatiânvua é emblemática, um certo apego à exposição didática pode explicar a tonalidade crua das metáforas via de regra construída numa relação direta entre a imagem e a situação que ela quer exprimir. A reiteração de alguns elementos como o brilho do diamante em contraste com a opacidade das vidas dominadas pela exploração e pela carência reforça a convicção desse ponto de vista onde se recortam as linhas da exemplaridade reputada como imprescindível ao esforço do momento. Se parece raso o vôo da imaginação na composição da linguagem, os limites devem ser vistos em consonância com a inserção do texto na história que a literatura ajuda a fazer e a contar.

R econhecendo um movimento especial na floresta, o narrador escapa às tendências folclorizantes e converte-a em algo mais que um cenário exótico. Para seu interior é transplantada a complexidade da vida urbana, o que significa que existem ali aspectos que impedem que se veja nela certas marcas para satisfazer a sede de exotismo de quem procura na literatura africana o colorido típico dos folhetos de turismo e que caracterizavam grosso modo as páginas da literatura colonial. O destaque conferido à floresta, a ênfase com que se descreve a sua exu- 
berância, a atmosfera meio mágica de seu interior não concorrem para sua idealização. Politizado, o Mayombe é lugar de conflito e contradição, podendo, portanto, ser visto como uma representação de Luanda, a capital do país, onde a luta ia ganhando força e onde, em novembro de 75 , se proclama a independência do país.

\section{Faz-se uma nação e perde-se um sonho}

Os anos que separam no tempo a escrita do Mayombe do momento em que Pepetela escreve A geração da utopia foram vividos de forma intensa pelo escritor e pelo país que se formou após a declaração da independência em onze de novembro de setenta e cinco. Q uase 20 anos depois, a história de Angola, particularizada por um cotidiano de impressionantes dificuldades, sob a brutal atmosfera de uma guerra que vai conhecendo aspectos, aparências, razões e repercussões diferentes, comprova no jogo do cotidiano a dimensão insuspeita dos limites da vitória conquistada. M uito mais do que ousou prever o Comandante Sem M edo, o herói do Mayombe, os fantasmas perpetuaram e com a intervenção de outros elementos sacudiram a frágil sustentação da utopia que mediara o empenho, fundindo ética e estética no projeto literário angolano.

E scrito no começo dos anos 90 na cidade de B erlim, onde se instalou o autor para gozar de uma bolsa oferecida por instituição alemã, o novo romance procura fazer um balanço da utopia que, bem ou mal, havia mobilizado a geração que assina a independência. Será esse grupo, mobilizado de algum modo, para a aventura do Mayombe o objeto central dessa narrativa cuja tônica é dada pelo desgaste, pela sombra, pela amarga diluição de um projeto a duras penas imaginado. Se a tarefa é de avaliação, o movimento fundamental é o da memória que resgata fatos que possam propiciar a compreensão dos caminhos escolhidos. R evisitados, alguns locais e épocas viabilizam um olhar novo, despido agora do sonho e já tingido pelas cores do desencanto. De acordo com a proposta de rever e avaliar, o espaço secundariza-se e o ponto fulcral é o tempo, elemento estrutural que assume a primazia na condução do processo narrativo. O destaque dado ao termo "geração" com que se nomeia o romance será confirmado pelo desenvolvimento da narrativa.

Cronologicamente é longo o tempo do enredo : as ações se iniciam em 1961 e o último capítulo se fecha com um sugestivo "a partir de 1991". D urante essas três décadas, iniciou-se a luta armada pela independência , nasceu o país, ensaiou-se o projeto socialista, transcorreu a guerra de agressão movida pelo regime racista da África do Sul, intensificou-se a guerra civil entre o M PLA ea UNITA, assinaram-se alguns tratados de paz jamais concretizados na íntegra, optou-se pelo 
neoliberalismo, o multipartidarismo sucedeu o regime de partido único. As transformações foram sem sombra de dúvida extraordinárias e de tudo isso, em alguma instância, participou essa geração. Coube-Ihe gestar o projeto nacionalista, instituir um modelo de estado, investir na construção ou na fraude de uma sociedade orientada pelos valores socialistas, viver a passagem para os padrões neoliberais, enterrar, alterar ou arquivar a utopia que catalisara a resistência ao colonialismo. Desses problemas se ocupa o romance, procurando desvendar os enigmas que insidiosamente transformaram a projeção utópica do Mayombe nas sombras que obscurecem o país libertado.

Abrindo o texto que coloca essa geração como protagonista das grandes mudanças, o narrador remonta a um exame oral de seu tempo de estudante recém-chegado à metrópole. Ao iniciar uma frase com a palavra "portanto"- um traço do falar angolano - , o aluno é acidamente repreendido pelo professor que, em sua arrogância, humilha-o associando a peculiaridade de seu uso da língua à ignorância de quem vem das colônias. Desse modo, a singularidade que poderia ser entendida como um traço de identidade converte-se em "deficiência", prova, portanto, de inferioridade :

"Portanto, só os ciclos eram eternos."

( Na prova oral de Aptidão à Faculdade de Letras, em Lisboa, o examinador fez uma pergunta ao futuro escritor. Este respondeu hesitantemente, iniciando com um portanto. De onde é o senhor, perguntou o professor, ao que o escritor respondeu de Angola. Logo vi que não sabia falar português, então desconhece que a palavra portanto só se utiliza como conclusão dum raciocínio ? Assim mesmo, para pôr o examinando à vontade. Daí a raiva do autor que jurou um dia havia de escrever um livro iniciado por essa palavra. Promessa cumprida. E depois deste parêntesis, revelador de saudável rancor de trinta anos, esconde-se definitiva e prudentemente o autor.)." ${ }^{5}$

Como se pode notar, o incidente é retomado em tom de blague por aquele que, quando nada, conquistou, ao longo dessas décadas, pelo menos, o direito de empregar na dimensão mais sagrada da escrita a expressão rejeitada no plano da oralidade por um representante da prepotência colonial. A "deficiência" ganha estatuto de estilo no palco glorificado da criação literária. Na referência, indicia-se o ambiente da metrópole povoada pelos preconceitos em relação ao que vinha da Á frica e, sutilmente, remarca-se a tonalidade irônica que tingirá a narrativa. Cumprida a promessa de trinta anos atrás, o narrador ao fechar o parêntesis, anuncia que o autor se vai retirar da cena : defi nitiva eprudentemente- promessa que não será cumprida. Visceralmente ligada ao processo que relata, sua fala. é contagiada pelos fatos que o olhar vai seleci- 
onando. O parágrafo seguinte, dominado pela sensação de distanciamento dada pelo uso do verbo no pretérito imperfeito do indicativo, não será propriamente paradigmático da totalidade da obra que virá, frequentemente, entremeada de interrogações, expressões dubitativas, sintomaticamente cortada por construções indicativas da perplexidade em relação à história vivida.

Cobrindo um longo período de tempo - dos anos que antecedem à aventura do Mayombe à fase já posterior à independência - o enredo acompanha a gestação, a tentativa de implantação e a falência do projeto utópico que estaria na base da história recente do país e no processo de criação de uma obra cujo eixo gira, como fomos previamente informados, em torno da formação da nacionalidade. Dos quatro capítulos, dois referem-se à preparação e conquista da independência e dois abordam a fase posterior. Em todos eles, porém, avivam-se sinais negativos e o leitor pode, desde as primeiras páginas, captar a dimensão das dificuldades a inviabilizar a utopia. Prenunciados na etapa ainda sonhadora do Mayombe, os problemas ampliam-se e se intensificam, deixando pouca margem para o otimismo.

As ações preconizadas, os procedimentos entrevistos, os modelos defendidos e as atitudes condenadas que compuseram o universo do Mayombe se vão desenrolando no decorrer do tempo e da narrativa dividida em quatro longos capítulos : “A casa ( 1961 )", "A chana ( !972)", “O polvo ( 1982 )" e "O templo (a partir de 1991 )". A recorrência a marcas espaciais que aí verificamos é logo relativizada pelo peso do tempo, materialmente referido na sequência do título de cada segmento do romance. A explicitação dos períodos revela também que o tempo de duração dos episódios se vai reduzindo , o que significa que as mudanças de que trata o texto se fazem de forma cada vez mais rápida. Observe-se ainda que o último capítulo inicia-se com um " a partir", sugerindo a continuidade de uma situação que deixa apreensivo quem de alguma maneira embarcou na travessia do Mayombe.

O contato com o texto comprova que, sob o compasso da memória, a dimensão temporal aciona a máquina que ao rever lugares e situações encontra na perspectiva da distância as chaves com que agora julga necessário abrir os cantos que ficaram obscurecidos pela urgência da mudança. Inversamente à ordenação meridiana do enredo do Mayombe, o romance expressa estruturalmente as hesitações, as angústias, as atormentadas vivências no interior de um processo cercado pelos perigos que não se extinguiram com o fim do colonialismo português. Os abalos na cronologia, com a incorporação do ritmo às vezes alucinado da memória, materializam-se no uso do discurso indireto livre, na intromissão desordenada 
de um narrador que se aproxima, se afasta, se mistura ao narrado, como um reflexo das contradições que atravessam os atores dessa História.

E m "A casa", a narrativa centra-se, como não é raro na obra de Pepetela, na perspectiva de um olhar feminino que procura compreender as rupturas em processo no grupo de estudantes da Casa dos Estudantes do I mpério e perceber as linhas da crise detonada com o início da luta armada em Angola. A agudização dos problemas raciais em Portugal, o cerco da Polícia Política, a animosidade surgind o na relação entre os que se tinham como companheiros, as crenças e opções da juventude fora da terra, tudo isso vai armando um quadro significativo de referências dessa época de difíceis definições. De um lado, as exigências, os programas e as interdições; do outro Angola e um complicado processo de luta. Narrado em terceira pessoa, acolhendo dados que confirmam a onisciência da voz que conta, o capítulo, a todo momento, é povoado pelas interrogações de Sara, uma estudante de medicina, nascida em B enguela, filha de comerciantes brancos economicamente bem situados. Sensível e progressista, ela vive a experiência das tensões raciais que se levantam com a eclosão da luta armada com repercussão quase imediata na metrópole. No momento em que o ânimo geral se prende à formulação de projetos para a construção nacional, ela funciona um pouco como uma espécie de duplo desse narrador claramente envolvido com aquilo que narra.

No segundo capítulo, "A chana", cujas ações localizam-se já no espaço da luta concreta, tendo os guerrilheiros como personagens centrais, altera-se o tom e o ponto de vista da narrativa. R adicalizando alguns sinais captados nas matas do $M$ ayombe, aqui é perfeitamente possível detectar as contradições e insuficiências que levariam aos desvios do projeto em parte tão alimentado na "Casa". Na dureza das ações, a solidariedade já não é a tônica e os procedimentos divisionistas cumprem a terrível função de anunciar a precariedade da vitória. O desencanto parece chegar antes do fim da guerra de libertação e o discurso do narrador não oculta o sentimento de frustração a prenunciar a descrença. O clima favorável à identidade dos primeiros tempos da luta se dilui. A possibilidade de comunhão de que a terna aproximação entre o narrador e Sara parecia ser uma imagem converte-se em discreto afastamento, numa relação que se faz também com as pontas de uma boa dose de ironia.

O clima de diálogo predominante em Mayombe desaparece e as conversas são atravessadas pelos sinais da incomunicabilidade. A incompreensão, a rivalidade, as intrigas manifestas ou tão-somente sugeridas fazem prever a irrealização dos propósitos que teriam levado à luta. O projeto de uma nação livre se vai estiIhaçando na condução de um processo inicialmente banhado pela generosidade de um sonho coletivo. A utopia tem como adversário os próprios homens que investiam em sua construção. As diferenças deixam de ser diversidade para se trans- 
formarem em capital de negociação, em patrimônio para obtenção de vantagens na sociedade ainda em formação.

Os anos saltam no desenrolar do enredo e o terceiro capítulo - "O polvo" tem como vetor A níbal, o Sábio, como ficou conhecido nos anos de guerra e clandestinidade. A sabedoria aí está diretamente ligada aos valores cunhados na esfera da lucidez, da responsabilidade, da coerência. O tempo correu, a luta pela independência política se fez, o inimigo comum foi derrubado, todavia levantaram-se os fantasmas previstos e mais aqueles que não se fizeram prever. O leitor deparase com uma sociedade marcada pela corrupção, pela falta de escrúpulos, pela irresponsabilidade social. A causa revela-se perdida e o duplo do narrador mistura-se ao cáustico olhar daquele que, farto de ser derrotado pela imposição de um conjunto de normas que pensou ver afastado com o fim do colonialismo, retira-se para um lugar distante e ali empenha sua incrédula resistência.

Com o foco centrado no olhar de um homem que se posta ao longe, esse capítulo tem o clima balizado por uma espécie de acerto de contas que se faz mediado pela exposição de vários confrontos. Nessa etapa, retomam-se alguns fios deixados soltos no contexto de Lisboa : Sara e Aníbal levam à raiz a comunhão já experimentada nos tempos de estudantes; remanescências do projeto revolucionário presentificam-se exigindo que a situação se confronte com a própria $\mathrm{H}$ istória : ali se colocam frente a frente os vencedores e os novamente vencidos. $M$ ais que todos esses, porque revela-se emblemático, situa-se o encontro de A níbal com o polvo. Dando continuidade a um episódio contado por ele a Sara, no primeiro capítulo, Aníbal que, orientado pelo seu desencanto retira-se para a praia da Caotinha, mergulha naquelas águas sempre mobilizado pelo desejo de reencontrar o polvo, o enorme polvo que sua memória convertera em entidade mitológica. Para aquele pedaço do país, afastado da capital e de qualquer centro de decisão, fica transferido o palco onde se vai dar um grande combate, o combate de um homem disposto a preservar-se inteiro com seus próprios monstros, com seus medos e seus limites. Inteiro, mas isolado, impotente para lutar contra outras feras, A níbal compõe a imagem do espírito das chanas do L este, miticamente identificado com o sonho que o conduziu à luta pela independência. A alusão a essa força no fim do capítulo exprime a hipótese de que adormecida a utopia pode um dia acordar.

Se o terceiro capítulo se fecha com a possibilidade, ainda que longínqua de mudança, o quarto e último faz cair sobre os leitores uma sombra desanimadora. O palco é a cidade de Luanda e os personagens que por ela circulam de maneira sinistra em nada permitem lembrar a crença num país novo e justo que havia mobilizado a geração. O empenho, a ingenuidade, a convicção política, mesmo a leve irresponsabilidade, enfim todos os elementos que se misturavam para com- 
por a atmosfera da "Casa" desaparecem cedendo lugar para a perversidade de um ambiente dominado pela mesquinharia. O vazio sobrepõe-se a tudo e se a dimensão religiosa do marxismo podia ser apontada como um patrimônio arcaico, a modernidade erguida sobre os valores do neoliberalismo desaba sobre o país e institui o caos. A sociedade que investiu numa proposta socialista, que nunca se consumou, assiste à implantação de um outro projeto do qual a solidariedade não consta, sequer como palavra de ordem.

O foco central recai sobre Vítor, o antigo guerrilheiro agora ministro, e Malongo, o ex-jogador de futebol, tornado empresário. Ligados ambos à "Casa", tiveram suas trajetórias apartadas durante as décadas de luta e de fundação do novo país. Vítor postou-se no centro das decisões, vivenciou de perto as mudanças desses anos. Malongo viveu fora e só regressa à terra quando, abandonada a opção socialista, a liberalidade da economia abre-se como uma promessa "a quem sabe investir". Separad os por muito tempo, os dois reúnem-se em torno do projeto de enriquecer, operação que será facilitada pela ligação com Elias, estranho personagem, cujo cinismo revestido por um discurso religioso será providencial para dar corpo ao desejo dos outros dois. Nesse capítulo, consagra-se a diluição de qualquer sinal na direção de uma sociedade mais justa. Como é dominante nos países periféricos, com o neoliberalismo instala-se o jogo do "salve-se quem puder". A ordem é acumular e cada um há de usar o capital de que dispõe. A os que estão no centro do poder ou em suas imediações apresenta-se o recurso de privatizar em seu próprio nome os bens públicos que deveriam administrar. Se o E stado de orientação socialista mostrava-se ineficiente, o modelo que o vai substituir será baseado, na apropriação indevida, na capitalização do prestígio pessoal ou institucional, nas técnicas da rapinagem ali cobertas pelos eufemismos que o próprio sistema elabora para se autojustificar.O quadro apresentado não deixa margem para expectativas outras. O enfraquecimento do poder público, apontado pela cartilha neoliberal como um fator de progresso, depara-se com uma sociedade civil desorganizada, despreparada para regulamentar, fiscalizar, corrigir abusos. Insidiosamente a descrença transforma-se na nota dominante e eleva-se como força mediadora das relações entre os homens.

Sob essas sombras, a narrativa vai se aproximando do final. Seguindo a evolução cronológica dos fatos, a organização dos capítulos registrou alguns dos impasses e as tantas limitações do projeto acalentado tendo por horizonte a libertação do país. A matéria é vasta e as dificuldades que impõe talvez expliquem certas fragilidades do romance. Diante da multiplicidade de elementos com que se depara, o narrador parece também ele fadado ao papel de vítima de um mundo em turbilhão. M uito diferentemente do que acontece em Mayombe, onde as contradições vêm enriquecer o ponto de vista da narrativa, em A geração da utopia 
as perplexidades desse universo em decomposição insinuam-se atingindo a voz que se queria soberana na narração dos fatos. $O$ texto assim parece-nos em certos momentos aquém da proposta; como se a ironia sentida nas primeiras páginas se esvaísse impotente no embate com os monstros contra os quais se lança. Diante da lembrança do arrogante professor, o narrador ergue-se debochado, atualiza o desprezo acumulado durante anos e cumpre a promessa de começar um romance por "portanto". E nvolvido na insidiosa sequência dos fatos que interditam a utopia, ele é asfixiado e, em certas passagens o leitor pode sentir que lhe falta fôlego. Como não se define propriamente como um recurso de expressão, essa aparente debilidade do narrador contribui para que se reduza em alguns momentos a fluência da narrativa.

Esse processo de esvaziamento da força narrativa pode ser percebido, por exemplo, no confronto entre a abertura e os parágrafos que antecedem o fecho do romance. No primeiro capítulo, inclusive as passagens anteriormente aqui transcritas, primam por uma força que nascendo da concisão sugere a imagem de um narrador convicto dos procedimentos que escolhe. A energia descritiva se articula com tonalidades poéticas dando ao texto um ritmo especial capaz de combinar trechos digressivos com certos sinais que sintomatizam o tom acelerado de algumas ações ali apanhadas. As imagens ricas ganham ainda maior densidade no jogo discursivo em que os diálogos se mesclam com as voltas do discurso indireto livre. Os planos se misturam resultando num interessante painel para exprimir a riqueza de uns anos tocados pela utopia. A vivacidade do momento é acompanhada pela linguagem e o texto espelha de forma dinâmica as relações que compõem o contexto.

Tal como a ambiência da "casa" referida no título, o romance promete. Mas, acompanhando a trajetória da sociedade a que está ligado, os sentidos se confundem, diluindo-se bastante a energia pressentida nesse começo, indicando, quem sabe, que o beco sem saída em que a sociedade angolana se vê sitiada não abre muitas possibilidades de expressão. Para fugir ao cerco opta-se pelo delírio como vetor da linguagem e as últimas páginas são povoadas por uma sucessão de frases descosidas, onde as elipses alternam-se com as repetições, a sintaxe dispensa a pontuação convencional, tudo contrariando a objetividade que um balanço requer. A intencionalidade desses procedimentos é nítida, todavia o resultado fica aquém dos objetivos. A té mesmo a racionalidade da argumentação do sábio A níbal, malgrado suas sérias intenções, se esbate sem dar conta dessa realidade multiforme em sua desagregação. Num mundo assim, onde os cinco sentidos mostram-se insuficientes para compreender o real, a linguagem também parece frágil para refletir vivamente os movimentos dos seres e das coisas. Por isso talvez, ao acabar a leitura, guarde-se um gosto de insatisfação. Ao leitor ficam, pelo menos, duas hi- 
póteses : se num primeiro momento tende a atribuir esses sinais de frustração à imperícia do narrador, numa segunda leitura pode interpretar o fenômeno como sintoma de coerência entre o campo temático e o plano estrutural. $O$ fato é que também nós, os leitores nos ressentimos do sonho perdido durante esses tempos que acreditávamos ser de construção da nação angolana.

\section{Perde-se uma nação. Desfaz-se a utopia?}

Fechado o último capítulo, o narrador que não cumprira a promessa de "definitiva e prudentemente" ocultar-se, reaparece no espaço a que chama epílogo para não encerrar a estória. A frase é curta e, fugindo às conclusões a que as análises devem conduzir, investe, uma vez mais, na continuidade da dúvida. R enovada, a perplexidade não permite respostas : abre-se a narrativa para o mundo que eterniza-se em movimento. E m constante rotação, tal como a história do país que ajuda a fazer e a contar, a obra de Pepetela redimensiona-se e ao pessimismo trazido pela derrota juntam-se algumas franjas da utopia despedaçada pela dureza de um contexto hostil. Nas obras seguintes, os problemas serão retomados, o processo histórico de Angola outras vezes revisitado, confirmando que o tema da construção nacional permanece, seja nas imagens multiplicadas da ruína de Luanda, alegoria central de O desejo de Kianda, seja na memória do escravo mudo que em A gloriosa família (sua mais recente publicação) relata as aventuras da família Van Dum na cidade sob o domínio dos holandeses.

Entre a empolgação que cercou os anos 70 e os desencantados anos 90 , a sociedade angolana viveu convulsivamente os dilemas e as impossibilidades a que está sujeito um país em construção. A pós décadas de guerra, o panorama é ainda feito de anúncios de paz que se sucedem sem que a população consiga ver além da destruição impiedosa das cidades, dos massacres no campo, da inviabilidade da vida intensificando o sentido de urgência de quem não ousa prever a hora seguinte. A violência diária e a imprevisibilidade do momento seguinte constituem fatores de perturbação elevada mesmo no cotidiano de uma gente que aprendeu a conviver com a precariedade e o enfrentamento. Tudo levaria ao desânimo, todavia a consciência da amargura desse tempo não permite que se dê a história por encerrada. Por entre os espaços mínimos, a literatura angolana, que se consolidou com o projeto da libertação, vai encontrando brechas para driblar a desesperança. Por isso, mesmo fragilizado pela força dramática do contexto a que claramente se refere, mesmo apresentando (ou representando ?) alguma debilidade no exercício de sua função, mesmo parecendo (com seus duplos) impotente para

$6 \quad$ Idem, p. 316 
“Como é óbvio, não pode existir epílogo nem ponto final para uma estória que começa por portanto"6

Portanto...

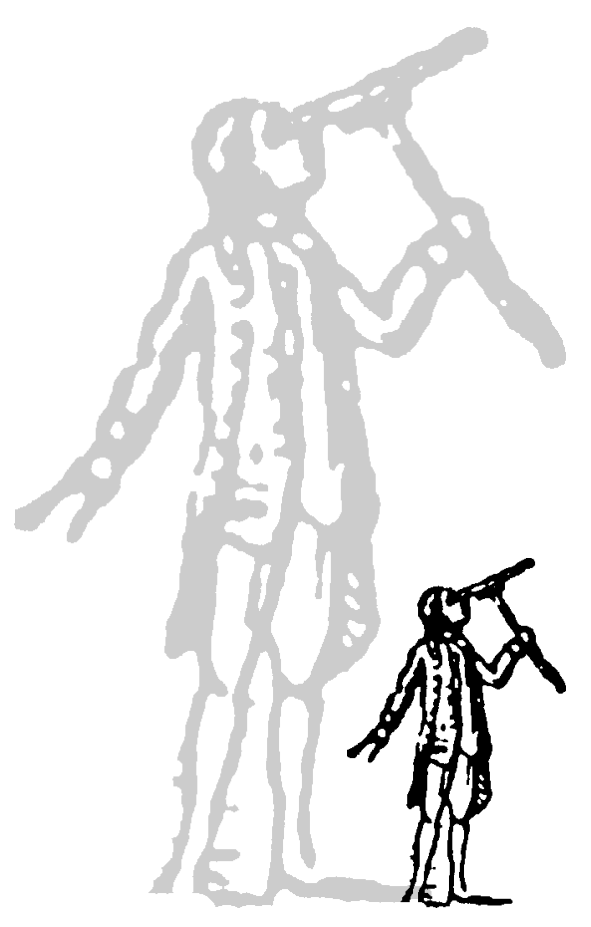

